http://dx.doi.org/10.12775/szhf.2018.061

\author{
MarTa ŚLIWA \\ Uniwersytet Warmińsko-Mazurski, Olsztyn, Polska \\ ORCID: 0000-0001-8796-511X \\ E-MAIL: MARTA.SLIWA@UWM.EDU.PL
}

\title{
Działalność Towarzystwa Filozoficznego w Aberdeen na tle szkockiego oświecenia
}

Unia parlamentarna pomiędzy Anglią a Szkocją, która miała miejsce w 1707 roku, wprowadzała podległość Szkocji, jednocześnie dość nieoczekiwanie doprowadziła do jej niezwykłego rozwoju. Zastanawiając się nad fenomenem szkockiego oświecenia ${ }^{1}$, nazywanego „wiekiem doskonalenia”, win-

${ }^{1}$ Szkockie oświecenie jest szczególnym ruchem intelektualnym związanym z ważnymi przemianami polityczno-ekonomiczno-społecznymi, jakie miały miejsce w XVIII-wiecznej Szkocji. Zob.: Stefan Zabieglik, Historia Szkocji, Gdańsk: Wydawnictwo DJ, 2000; Paweł Hanczewski, “The Union of 1707 and the Scottish Enlightenment," Ruch Filozoficzny, 74, no 3 (2018): 7-22. W literaturze przedmiotu możemy znaleźć wiele określeń i definicji tego okresu: mówi się o szkockim oświeceniu (The Scottish Enlightenment), o wieku postępu, wieku doskonalenia (The Age of Improvement) czy też złotym wieku Szkocji (The Golden Age). Wiek doskonalenia, którego największy rozwój przypada na lata 1730-1800, miał kilka charakterystycznych cech. Jedną z nich był rozwój nauk o naturze ludzkiej i naturalnej filozofii, stanowiący podstawę do tworzenia się nowożytnych nauk społecznych, i opierający się, jak twierdzi jeden z wybitnych badaczy tego okresu, Roger L. Emerson, na „kosmopolitycznym społeczeństwie wiedzy”. Zob: Roger L. Emerson, "Science and the Origins and Concerns of the Scottish Enlightenment," History of Science 26, (1988): 333-366; Craig Smith, "The Scottish Enlightenment, unintended consequences and the science of man", The Journal of Scottish Philosophy 7, no 1, (2009): 9-28; Ryan Patrick Hanley, "Social science and Human Flourishing: The Scottish Enlightenment and 
niśmy zwrócić uwagę na aktywność największych intelektualnych umysłów XVIII-wiecznej Szkocji, w ramach ich działalności na płaszczyźnie czysto naukowej, uniwersyteckiej, a także społecznej. W tym miejscu warto podkreślić aktywność specjalistycznych towarzystw i klubów, które stanowiły arenę wymiany idei, myśli, gorących stricte naukowych dysput, rozpowszechniania wiedzy, jak również były to miejsca spotkań czysto towarzyskich pomiędzy uczonymi z różnych dziedzin. Towarzystwa w oświeceniu były powszechne, w Szkocji - były wyjątkowo liczne i aktywne. Różniły się swoją specyfiką, niektóre miały typowo teoretyczny, inne bardziej praktyczny charakter. Były to towarzystwa ukierunkowane na konkretne dyscypliny naukowe i branżowe, w tym: medyczne, filozoficzne, geograficzne, muzyczne, dotyczące sztuk mechanicznych, rolnictwa czy architektury. Cześć z nich miała charakter elitarny - ich członkami byli wybrani uczeni, część umożliwiała uczestnictwo bardzo różnym grupom społecznym: od profesorów uczelni, lekarzy, właścicieli ziemskich po drukarzy, rzemieślników czy farmerów. Ich liczba i różnorodność jest imponująca. Towarzystwa i kluby skupiały się głównie wokół uniwersyteckich miast XVIII-wiecznej Szkocji: Edynburga, Aberdeen, Glasgow i St. Andrews. Szczególnie wysoki naukowy poziom reprezentowały: Towarzystwo Filozoficzne w Edynburgu (The Philosophical Society of Edinburgh, przekształcone w 1783 roku w Royal Society of Edinburgh), Towarzystwo Literackie w Glasgow (Literary Society, 1752-1788) i Towarzystwo Filozoficzne w Aberdeen (The Aberdeen Philosophical Society, 1758-1773).

Funkcjonowanie Towarzystwa Filozoficznego w Aberdeen, a przede wszystkim aktywność jego członków, jest tematem niniejszego artykułu. Udokumentowana działalność tego elitarnego i typowo naukowego Towarzystwa stanowi bowiem niezwykle cenne źródło informacji o kształtowaniu się myśli filozoficznej w samym Aberdeen, jak i w całej oświeceniowej Szkocji.

W XVIII-wiecznym Aberdeen funkcjonowały dwa uniwersytety: Marischal College w obrębie nowego miasta i King's Collage w Starym Aberdeen.

today", The Journal of Scottish Philosophy 7, no 1, (2009): 29-46. Christopher Berry (The Idea of Commercial Society in the Scottish Enlightenment. Edinburgh: Edinburgh University Press, 2013. 256) opisuje ten ruch jako samoświadomość Szkotów dotyczącą własnego społeczeństwa rozumianego jako nowa, wyjątkowa, społeczna i polityczna formacja. Co ciekawe, formacja, która jak na ówczesne standardy europejskie, nie była liczna. Populacja Szkotów w 1700 roku wynosiła ok. 1100 000, a w 1800 roku - 1600 000, przy czym grupę oświeconych Szkotów szacuje się na ok 550 000-800 000. Zob. Roger L. Emerson, Essays on David Hume, Medical Men and Scottish Enlightenment: Industry, knowledge and Humanity. London: Routledge, 2016, Chapter 3, How many Scots were enlightened? 
Pierwszy ukierunkowany był na nauki przyrodnicze, drugi zaś wykazywał specjalizację w naukach teologicznych i filozoficznych. W 1760 roku w mieście funkcjonowały trzy towarzystwa: Towarzystwo Rolnicze (Gordon Mills Farming Clubs), Towarzystwo Filozoficzne (Aberdeen Wise Club) i Towarzystwo Muzyczne (Musical Society). Pomimo różnorodnej specjalizacji tych towarzystw ich członkowie często należeli jednocześnie do kilku klubów. Bardzo ciekawe zestawienie przedstawia Roger Emerson, przyjmując, iż w roku 1760 w samym Aberdeen było ok. 50 uczonych mężów, a 12 z nich, będąc jednocześnie akademikami wchodziło w skład Towarzystwa Filozoficznego.

Liczba „Oświeconych” w Aberdeen, 1760 rok

\begin{tabular}{l|c}
\hline Aberdeen & \\
\hline Universities & 20 \\
\hline Gordon Mills Farming Clubs & 13 \\
\hline AWC (Aberdeen Wise Club) & 20 \\
\hline Musical Society & 40 \\
\hline Aberdeen total & 85 \\
\hline (minus duplicates) & c.50 \\
\hline
\end{tabular}

Rys. 1. Fragment tabeli przedstawiającej The Visible Enlightened, 1760 według R. L. Emersona (Emerson, Roger L. Essays on David Hume, Medical Men and the Scottish Enlightenment. Abingdon, Oxon, GBR: Ashgate Publishing Group, 2009: 44)

W 1758 roku z inicjatywy Thomasa Reida i jego kuzyna Johna Gregory'ego powstało w Aberdeen Towarzystwo Filozoficzne znane powszechnie jako Klub Mądrości (The Wise Club)². Towarzystwo działało nieprzerwanie do 1773 roku. Piętnaście lat jego systematycznego działania jest bardzo dobrze udokumentowane. W kolekcji specjalnej Biblioteki Uniwersytetu w Aberdeen $^{3}$ znajdują się oryginalne dokumenty Towarzystwa, w tym wykaz pre-

\footnotetext{
${ }^{2}$ W literaturze spotykamy się również z tłumaczeniem The Wise Club jako Klubu Mędrców.

${ }^{3}$ Oryginalne dokumenty Towarzystwa Filozoficznego w Aberdeen z lat 1758-1773 o sygnaturach: GB231 MS 0145 i GB 231 MS 0539 znajdują się w kolekcji specjalnej Biblioteki Uniwersytetu w Aberdeen. Zostały opublikowane w opracowaniu autorstwa Lewisa H. Ulmana, Minutes of the Aberdeen Philosophical Society, 1758-1773, Aberdeen University Studies Aberdeen University Studies, 158, (Aberdeen: Aberdeen University Press, 1990).
} 
zentowanych w czasie spotkań rozpraw i zgłaszanych do nich uwag, zasady i sprawozdania Towarzystwa oraz jego roczne rozliczenia pieniężne.

W skład założycieli Wise Club wchodzili: George Campbell (1719-1796), profesor teologii Marischal College, nauczyciel T. Reida; Thomas Reid (1710-1796), regent w King’s College, później profesor filozofii moralnej, Glasgow; John Stewart (1708-1766), profesor matematyki, Marischal College; Robert Trail (1720-1775), profesor języków orientalnych, później profesor teologii, Glasgow; John Gregory (1724-1773), profesor filozofii, a później profesor medycyny w King's Collage; David Skene (1731-1770), lekarz, dziekan Wydziału Marischal College.

Pierwszym dokumentem podpisanym przez członków założycieli, de facto wytyczającym kierunek Towarzystwu, były Zasady działalności Towarzystwa Filozoficznego w Aberdeen ${ }^{4}$. W bardzo skondensowany i niepozostawiający żadnych wątpliwości sposób przedstawiono w 17 punktach, krok po kroku, zarówno organizację samego Towarzystwa oraz jego spotkań, jak i kierunek rozważań naukowych. Począwszy od 12 stycznia 1578 roku, spotkania klubu miały się odbywać co drugą środę, o godzinie 17.30. Punkt trzeci Zasad wprowadza regulację dotyczącą spożywania trunków w czasie obrad, ponieważ co warto zaznaczyć - spotkania odbywały się w dwóch różnych tawernach ${ }^{5}$, zarówno w nowej części Aberdeen, jak i w jego Starym Mieście. Członkami Towarzystwa byli przecież profesorowie z Marischal College i King's College. Spotkania miały trwać 3-4 godziny, prowadzone winne być przez zmieniającego się co miesiąc przewodniczącego. Sam sposób wyboru przewodniczącego również był ściśle określony. Określone zostały zasady przyjmowania kolejnych członków oraz opłata wpisowa w wysokości pięciu szylingów. Najciekawsze z perspektywy poprowadzonych tutaj analiz są zasady precyzujące sam sposób funkcjonowania Towarzystwa, nakładające na każdego członka obowiązek przedstawiania 30-minutowego odczytu, rozprawy (discourse), której temat wcześniej zgłoszono. W przypadku niedopełnienia obowiązku w punkcie 13 czytamy:

4 „Zasady działalności Towarzystwa Filozoficznego w Aberdeen”, przekład i opracowanie: Marta Śliwa, Studia z Historii Filozofii, 4 (9)2018, 75-80.

${ }^{5}$ Zachowane zostały rachunki finansowe ze spotkań, które nawet przy późniejszym wzroście cen nie przekraczały 20 szylingów. Przykładowy rachunek zawierał następujące pozycje: 1 Mutchken Punch, 2 botles Red Port, 3 botles Porter, Supper, Pipes \& Tobacco, co zdaje się potwierdzać, iż pierwszym i niepodważalnym celem spotkań były dysputy intelektualne. Zob. E. H. King "A Scottish 'Philosopical' Club in the Eighteen Century", Dalhousie Review 50, (1971): 204. 
Jeśli któryś z członków Towarzystwa bez uzasadnionego usprawiedliwienia swojej rozprawy nie przedstawi lub na piśnie w wyznaczonym czasie jej nie prześle, Przewodniczacy, jako sędzia, nałoży na niego karę pieniężną w wysokości pół korony (dwa i pół szylinga) na rzecz Towarzystwa. Uiścić ją należy do czwartej środy następnego miesiąca pod groźbą powtórzenia tej samej kary $y^{6}$.

Po przedstawieniu rozprawy każdy członek Towarzystwa miał prawo zadać pytania (questions). Co ważne, zwrócono uwagę na sposób prowadzenia dyskusji i argumentacji, tak, by jak czytamy,

każdy członek Towarzystwa, po kolei, będzie miał możliwość w sposób nieskrępowany, acz bezstronny i życzliwy zgłosić swoje uwagi. Należy jednakże unikać krytyki wymowy czy też kompozycji, jest to bowiem obce zamysłom Towarzystwa ${ }^{7}$.

Skrupulatnie dokumentowano spotkania, protokołując tematy przedstawianych rozpraw i zadawanych pytań oraz wszelkie kwestie związane ze sprawozdawczością finansową Towarzystwa. Dokumenty te w większości przetrwały do naszych czasów.

Jak już wspomniano, Towarzystwo Filozoficzne w Aberdeen jest jednym z klubów w Szkocji prezentujących wysoki poziom naukowy, mający bardzo elitarny i typowo naukowy charakter. Elitarny - w całym bowiem okresie działania Towarzystwo miało tylko 15 członków. Wkrótce po określeniu Zasad założyciele zaprosili do Towarzystwa kolejnych dziewięciu członków. Byli to: John Farquhar (1732-1768), duchowny szkockiego kościoła; Alexander Gerard (1728-1795), profesor logiki i filozofii moralnej w Marischal College, później profesor teologii w King's College; Thomas Gordon (1714-1797), profesor humanistyki w King's College; John Ross (1730-1800), profesor hebraistyki w King's College; James Beattie (1735-1803), profesor filozofii i logiki w Marischal College, filozof i poeta; William Ogilvie (1736-1819), profesor filozofii, późniejszy profesor humanistyki w King's College; James Dunbar (1742-1798), regent w King's College; William Trail (1746-1831), profesor matematyki w Marischal College, późniejszy duchowny Kościoła Irlandii; George Skene (1742-1803), profesor filozofii przyrody, później profesor historii społecznej i naturalnej w Marischal College i lekarz. Jak widać, 14 z 15 członków Towarzystwa było nauczycielami akademickimi (jedynie

\footnotetext{
6 „Zasady działalności Towarzystwa Filozoficznego w Aberdeen”, 13.

${ }^{7}$ Ibidem, 14.
} 
John Farquahar nie pracował na uniwersytecie), czworo z nich było również duchownymi.

Charakter towarzystwa gwarantowała zarówno elitarność jego członków, jak i najważniejszy punkt Zasad, w którym określono tematykę podejmowanych dyskusji.

Tematem rozpraw i zgłaszanych do nich uwag winna być filozofia. Wszelkie debaty: gramatycznej, historycznej czy też filologicznej natury uznawać się będzie za obce zamysłom Towarzystwa. Jako problemy filozoficzne rozumie się: wszelkie zasady nauki, jakie można wywieść za pomocą rzetelnego i słusznego wnioskowania ze zjawisk zachodzących tak i w umyśle ludzkim, jak i w świecie materialnym; wszelkie spostrzeżenia i doświadczenia, jakie wnieść mogą materiał ku takiemu wnioskowaniu; badanie błędnych systemów filozoficznych i błędnych metod prowadzenia filozoficznego wywodu; podległości filozofii wobec nauk humanistycznych, zasadom, jakich im ona użycza, i środkom doprowadzania ich do doskonałości. Jeśli pojawiłby się jakiś spór o to, czy temat rozprawy lub uwaga do niej mieści się w rozumieniu i w intencji niniejszego artykułu, rozsądzi o tym większość członków Towarzystwa obecna na spotkaniu.

Nie dość zatem, iż Wise Club miał naukowy charakter, to jeszcze było to, tak w założeniach, jak i w praktyce, towarzystwo ściśle filozoficzne.

W trakcie funkcjonowania instytucji kilkoro spośród jego członków publikowało swoje prace. Nie ulega wątpliwości, że prace te przynajmniej częściowo były prezentowane i omawiane na posiedzeniach Towarzystwa. Reid był jednym z tych, który czerpał korzyści z gorących dyskusji, jakie miały miejsce na posiedzeniach. Biografowie uważają, iż bez zachęty ze strony członków Towarzystwa Filozoficznego nigdy by nie opublikował An Inquiry into the Human Mind upon the Principles of Common Sense ${ }^{9}$. W dniu 14 lipca 1758 roku na spotkaniu Towarzystwa omawiano kwestię dotyczącą percepcji wzroku, stanowiącą cześć Inquiry. Wówczas Reid, przedstawiając rozdział dotyczący doznań, tłumaczył, dlaczego zaczyna go od analizy wzroku: „Postrzeganie przez zewnętrzne zmysły wydaje się pierwszą, najprostszą i najbardziej wyraźną operacją umysłu, i dlatego należy ją najpierw rozważyć. Będę zatem czynił pewne obserwacje na temat percepcji, poczynając od wzroku"

\footnotetext{
${ }^{8}$ Ibidem, 17.

${ }^{9}$ Kathleen Holcomb, "Reid in the Philosophical Society." in The Philosophy of Thomas Reid, edited by Melvin Dalgarno and Eric Matthews, 413-20, (Kulwer Academic Publisher, 1989).
} 
(MS 3107/1/1/p.19 (14 June, 1758)) ${ }^{10}$. Na spotkaniu 14 marca 1759 roku Reid ponownie, wracając do tej kwestii, stwierdza, iż: „kolejność, w jakiej należy omawiać doznania, powinna dawać pierwszeństwo nie tym najszlachetniejszym i najbardziej użytecznym, ale najprostszym i tym, których obiekty są najmniej zagrożone myleniem się z innymi rzeczami - i mogą występować w następującej kolejności: wąchanie, smakowanie, słuch, dotyk i jako ostatni wzrok" (MS 3107/1/3/p.58 (14 March, 1759)) $)^{11}$. Reid był członkiem Towarzystwa przez sześć i pół roku, był jego sekretarzem przez pierwsze dwa lata, rok mu przewodniczył. Przedstawił dziewięć różnych odczytów, siedem z nich dotyczyło kwestii związanych z percepcją. Po publikacji Inquiry Reid przeniósł się do Glasgow, gdzie został profesorem filozofii moralnej. Pomimo aktywnego uczestnictwa w pracach Towarzystwa Literackiego w Glasgow, Reid utrzymywał kontakt $\mathrm{z}$ kolegami z Wise Club, dowiadywał się o rozwój Towarzystwa, bywał też dość często w Aberdeen, 13 sierpnia 1771 roku uczestniczył nawet w obradach klubu ${ }^{12}$.

Kolejnym uczonym, który publikował prace w trakcie swojej działalności w Towarzystwie, był John Gregory, profesor filozofii i medycyny, lekarz. Był dość aktywnym członkiem, przedstawił sześć rozpraw. W roku 1765 zostały one wydane w tomie Comparative View of the State and Faculties of Man with those of Animal World. Interesowały go zagadnienia związane z porównaniem władz człowieka i zwierząt, omawiał wpływ religii na ludzką naturę, pytał o podstawę smaku w muzyce. Jego ostatni odczyt dotyczył przedłużania ludzkiego życia i opóźniania starości. Często zadawał pytania, wśród których na uwage zasługuje pytanie dotyczące charakterystycznych cech dowcipu i humoru, czy to bezpośrednio odwołujące się do jego lekarskiej praktyki: czy sztuka medyczna, tak jak ją zwyczajowo praktykowano, przyczyniła się dla pożytku ludzkości? (zgłoszone 12 lipca 1764 roku). Kolejne prace autorstwa tego badacza powstały już za czasów jego obecności w Edynburgu i aktywności w Edynburskim Towarzystwie Filozoficznym ${ }^{13}$.

\footnotetext{
${ }^{10}$ Ibidem, 416.

${ }^{11}$ Ibidem, 417.

${ }^{12}$ Minutes of the Aberdeen Philosophical Society, 1758-1773, ed. by Lewis H. Ulman, Aberdeen University Studies Aberdeen University Studies, 158, (Aberdeen: Aberdeen University Press, 1990), 29-31.

${ }^{13}$ Ibidem, 27-28.
} 
Alexander Gerard uczestniczył w spotkaniach Wise Club w latach 1758-1771. Był znaczącą postacią w Towarzystwie, uczestniczył w większej liczbie spotkań i przedstawił więcej rozpraw (19) niż którykolwiek z jego kolegów ${ }^{14}$. W tym czasie zaprezentował odczyt na temat geniuszu oraz referat o wpływie namiętności na kojarzenie idei. O dużym zainteresowaniu tym tematem wśród członków Towarzystwa może świadczyć fakt, iż 22 kwietnia 1758 roku John Farquhar zaproponował następujący temat do dyskusji: „Na doskonałości jakiej władzy polega geniusz? A jeżeli na kombinacji różnych, to czym one są?". Rozgorzała gorąca dyskusja, podczas której Reid i John Gregory dość mocno krytykowali Gerarda. W wydanym w 1774 roku Essay on Genius czytamy, iż to siła wyobraźni jest prawdziwym źródłem geniuszu ${ }^{15}$.

Działalność Towarzystwa Filozoficznego w Aberdeen, pomimo że skupiała się głownie na wewnętrznej aktywności jego członków, na ich zainteresowaniach badawczych, miała zdecydowanie szerszy kontekst. Omawiano bowiem również koncepcje i publikacje prezentowane przez innych filozofów. Dość często pojawiały się w dyskusji krytyczne uwagi, szczególnie autorstwa Jamesa Beattiego, wobec sceptycyzmu Davida Humea. W liście Reida do Hume'a z 1763 roku, czytamy:

Tutejsze małe Towarzystwo Filozoficzne [...] jest Panu wielce zobowiązane za zatrudnianie nas. Pana towarzystwo, chociaż wszyscy jesteśmy dobrymi chrześcijanami, byłoby przyjęte przez nas lepiej niż kompania św. Atanazego. A ponieważ nie możemy mieć Pana na naszej ławie, jest Pan częściej niż kto inny wymieniany, oskarżany i broniony z wielką gorliwością, choć zawzięcie. Jeżeli nie napisze Pan nic więcej w zakresie moralności, polityki i metafizyki, to muszę z przykrością wyznać, ze stracimy tematy (do naszych dyskusji) ${ }^{16}$.

Trzeba pamiętać, że w niewielkiej, acz złotej XVIII-wiecznej Szkocji, funkcjonowały tylko cztery centra akademickie, więc mężowie nauki w większości się znali - jeżeli nie osobiście, to korespondencyjnie. Wymiana myśli była wartka. Fakt tak znakomitego udokumentowania działalności Towarzystwa pozwala prześledzić sposób kształtowania się idei oświecenia w kraju, który zadziwił swoim szybkim rozwojem. Wise Club szczególnie w zestawieniu

\footnotetext{
${ }^{14}$ Ibidem, 35-36.

${ }^{15}$ Margaret Lee Wiley. “Gerard and the Scots Societies," Studies in English, no. 20 (1940): 134.

${ }^{16}$ Thomas Reid, Works, t. 1, 92. Cyt. za: S. Zabieglik, Krzywe Zwierciadło filozofii, czyli dzieje pojęcia zdrowego rozsądku, (Warszawa: Książka i Wiedza, 1987), 195.
} 
z Towarzystwem Filozoficznym w Edynburgu ${ }^{17}$ odgrywał rolę „naukowej gildii” dla uczonych w Aberdeen, miejsca, gdzie poglądy kluczowych graczy szkockiego oświecenia mogły zostać poddane obróbce. I tak też było.

\section{Bibliografia}

Berry Christopher J. 2013. The Idea of Commercial Society in the Scottish Enlightenment. Edinburgh: Edinburgh University Press.

Emerson Roger L. 2016. Essays on David Hume, Medical Men and Scottish Enlightenment: Industry, knowledge and Humanity. London: Routledge.

Emerson Roger L. 1988. "Science and the Origins and Concerns of the Scottish Enlightenment." History of Science 26 : 333-366.

Hanczewski Paweł. 2018. "The Union of 1707 and the Scottish Enlightenment." Ruch Filozoficzny 74 (3) : 7-22.

Holcomb Kathleen. 1989. "Reid in the Philosophical Society." In The Philosophy of Thomas Reid, edited by Melvin Dalgarno and Eric Matthews. 413-20. Kluwer Academic Publisher,

King E. H. 1971. "A Scottish 'Philosopical' Club in the Eighteen Century", Dalhousie Review $50: 201-214$.

Lewis H. Ulman (ed.). 1990. Minutes of the Aberdeen Philosophical Society, 1758-1773. Aberdeen University Studies Aberdeen University Studies, 158. Aberdeen: Aberdeen University Press.

Smith Craig. 2009. "The Scottish Enlightenment, unintended consequences and the science of man." The Journal of Scottish Philosophy 7 (1) : 9-28.

Hanley Ryan Patrick. 2009. "Social science and Human Flourishing: The Scottish Enlightenment and Today". The Journal of Scottish Philosophy 7 (1) : 29-46.

Śliwa Marta. 2018. "Philosophical Societies in the Scottish Enlightenment." Ruch Filozoficzny 74 (3) : 107-117.

Zabieglik Stefan. 2000. Historia Szkocji. Gdańsk: Wydawnictwo DJ.

„Zasady działalności Towarzystwa Filozoficznego w Aberdeen”, przekład i opracowanie M. Śliwa. Studia $z$ Historii Filozofii 9 (4) 2018 : 75-80.

${ }^{17}$ Edynburskie Towarzystwo Filozoficzne miało bardziej praktyczny i bardziej społeczny profil niż Wise Club. Porównanie specyfiki towarzystw zob. M. Śliwa, "Philosophical Societies in the Scottish Enlightenment", Ruch Filozoficzny 74, no. 3 (2018): 107-117. 


\section{Streszczenie \\ Działalność Towarzystwa Filozoficznego w Aberdeen na tle szkockiego oświecenia}

Analizując fenomen szkockiego oświecenia nie można pominąć działalności specjalistycznych towarzystw i klubów, które stanowiły arenę wymiany idei, gorących, naukowych dysput, były miejscem rozpowszechniania wiedzy. Tematem niniejszego opracowania jest działalność elitarnego i typowo naukowego Towarzystwa Filozoficznego w Aberdeen, z podkreśleniem aktywności Thomasa Reida, Johna Gregory'ego i Alexandra Gerarda. Oryginalne dokumenty Towarzystwa: spisane reguły Towarzystwa, sprawozdania ze spotkań, wraz z opisem tematów podejmowanych dyskusji, pojawiających się pytań, czy sprawozdania finansowe stanowią niezwykle cenne źródło informacji o kształtowaniu się myśli filozoficznej w samym Aberdeen, jak i w całej oświeceniowej Szkocji.

Słowa kluczowe: Towarzystwo Filozoficzne w Aberdeen; Wise Club; Szkockie Oświecenie; Thomas Reid.

\section{Abstract \\ Activity of the Philosophical Society in Aberdeen in the Light of the Scottish Enlightenment}

When analyzing the phenomenon of the Scottish Enlightenment, the activities of specialized societies and clubs cannot be omitted. They served as a common ground for the exchange of ideas, hot scientific disputes, and dissemination of knowledge. This study is devoted to the activity of the elitist and typically scientific Philosophical Society in Aberdeen, with particular attention to the membership of Thomas Reid, John Gregory, and Alexander Gerard. The Society's original documents: its recorded rules, minutes of the meetings, descriptions of discourse topics, questions, or financial reports may serve as extremely valuable source of information regarding the shaping of the philosophical thought not only in Aberdeen itself, but also in the whole Scotland in the period of Enlightenment.

Keywords: The Philosophical Society in Aberdeen; The Wise Club; Scottish Enlightenment; Thomas Reid. 